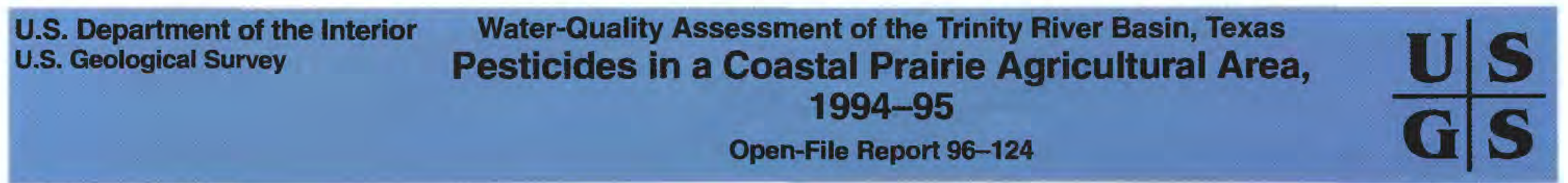

\section{-M.F. Brown}

\section{Abstract}

Agriculture is a major land use in the coastal prairie area located in the southern part of the Trinity River Basin. Crops grown in the area include rice, sorghum, and soybeans. Pesticide-use estimates for the area show that compounds with the highest use are the herbicides: molinate, propanil, thiobencarb, metolachlor, acifluorfen, bentazon, and atrazine and the insecticides: carbaryl and methyl parathion. More than 20 pesticide samples collected from each of three streams in the coastal prairie resulted in detections of 29 different pesticide compounds. The most frequently detected compounds were the herbicides: atrazine, metolachlor, and molinate, which were detected in more than 75 percent of the samples. Herbicides were detected more frequently than insecticides. Maximum concentrations of atrazine, metolachlor, and molinate occurred in the spring and were 4, 1.9, and 200 micrograms per liter $(\mu \mathrm{g} / \mathrm{L})$, respectively. Almost all concentrations of atrazine and metolachlor were below drinking water standards; no standard is available for molinate. Concentrations and estimated loads and percent of applied compound lost to the streams were generally higher in the watersheds where more of the pesticides were applied to crops.

\section{Introduction}

The Trinity River Basin was among the first 20 hydrologic systems under full implementation of the National Water-Quality Assessment (NAWQA) Program. Planning and analysis of existing information began in 1991. Intensive data collection began in 1993. With its mouth on Trinity Bay (fig. 1), the Trinity River contributes substantial amounts of freshwater to Galveston Bay, which was selected by Congress as an estuary of national significance and included in a priority list for the National Estuary Program. Previously, inflow to Galveston Bay from the Trinity River has been estimated from measurements 70 miles upstream from the mouth. As a part of the NAWQA study, the water quality in the coastal prairie area immediately upstream from the bay was assessed. The area has a complex hydrologic system and diverse land use that includes rice farming with irrigation diversions and return flows. Pesticide samples were collected from streams in three watersheds in the coastal prairie area near Dayton and Anahuac, Texas (fig. 1), during 1994-95. This report discusses the results of that sampling along with land use, crops, and pesticide use in the three watersheds.

\section{Study Area Description}

The southern part of the Trinity River Basin can be described as a coastal prairie with almost level relief, clay-rich soils, and a subtropical climate. The coastal prairie makes up about 5 percent $(2,230$ square kilometers $)$ of

the Trinity River Basin. The area receives an average of 134 centimeters $(\mathrm{cm})$ or 53 inches (in.) of rainfall per year. In calendar year 1994, $152 \mathrm{~cm}$ (60 in.) of rain fell at Anahuac and 178 $\mathrm{cm}$ (70 in.) fell in the Dayton area (National Oceanic and Atmospheric Administration, 1994). The coastal prairie is the only area within the river basin where rice is grown. Because of the water requirements for rice, a more complex hydrologic system of rice irrigation canals and drainage canals for return flows is required. Natural drainage has been altered because of roadways and drainage canals in the flat terrain. An example of the hydrologic system in one of the coastal prairie watersheds, West Prong Old River, is shown in

Table 1. Watershed size, land use, and crops

$\left[\mathrm{km}^{2}\right.$, square kilometers; - , no data]

\begin{tabular}{|c|c|c|c|c|c|c|c|}
\hline \multirow{2}{*}{ Watershed } & \multirow{2}{*}{$\begin{array}{c}\text { Drainage } \\
\text { area } \\
\left(\mathrm{km}^{2}\right)\end{array}$} & \multicolumn{3}{|c|}{$\begin{array}{l}\text { Land use } \\
\text { (percentage of watershed area) }\end{array}$} & \multicolumn{3}{|c|}{$\begin{array}{c}\text { Crops } \\
\text { (percentage of watershed area) }\end{array}$} \\
\hline & & Urban & $\begin{array}{l}\text { Agricul- } \\
\text { ture }\end{array}$ & Forest & Rlce & Sorghum & Soybeans \\
\hline East Fork & 112 & 25.4 & 73.2 & 0.6 & 10.5 & - & - \\
\hline Whites Bayou & 28 & 2.6 & 53.7 & 43.7 & 4.8 & - & - \\
\hline West Prong & 75 & 4.4 & 92.2 & 2.1 & 5.6 & 5.9 & 20 \\
\hline
\end{tabular}

\section{EXPLANATION}

Trinity River Basin

Gaged Watersheds:

East Fork Double Bayou

Whites Bayou

West Prong Old River

Surface-water sampling site

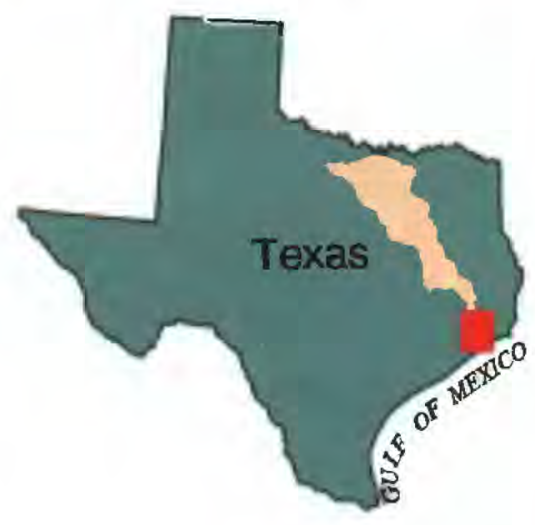

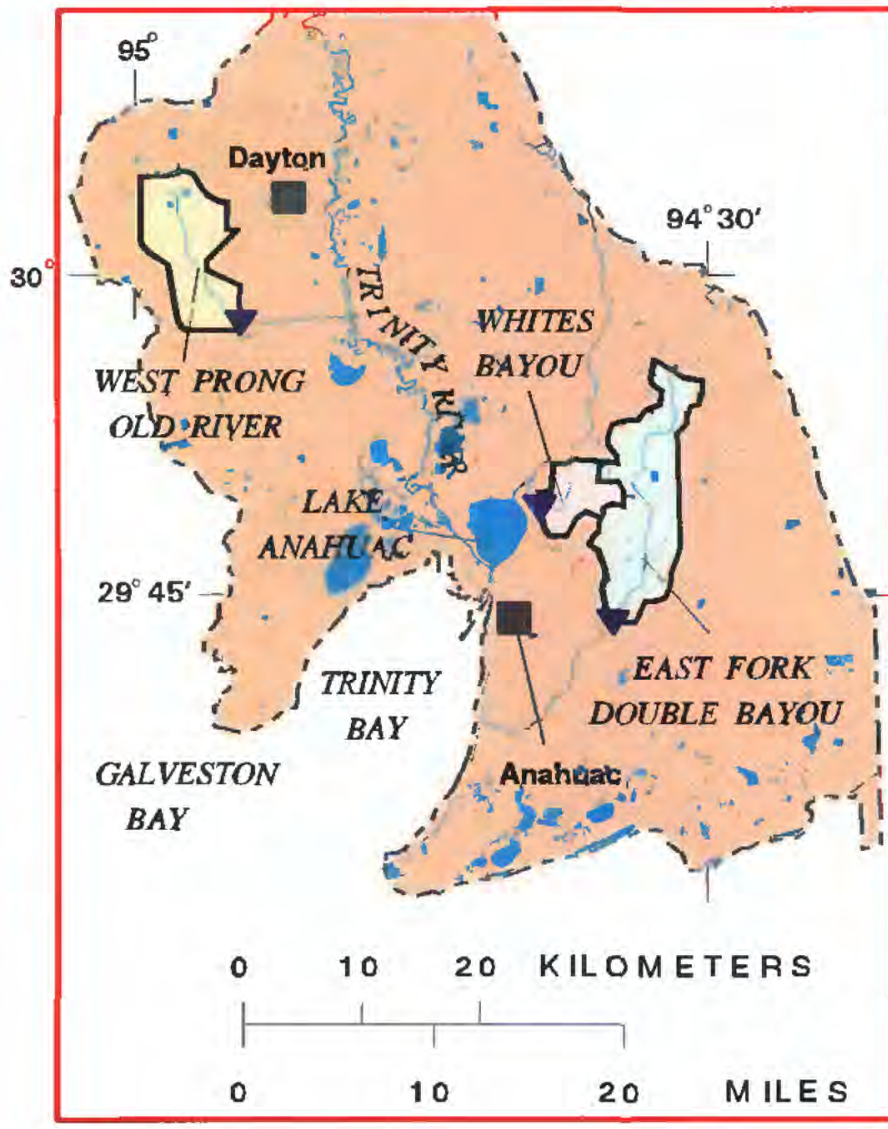

Flgure 1. Location of Trinity River Basin and coastal prairie area, Texas. 
figure 2. Other agricultural activities in the area include the production of grain sorghum and soybeans as well as cattle ranching.

Three watersheds, East Fork Double Bayou (or simply East Fork), Whites Bayou, and West Prong Old River (West Prong), which give spatial coverage and represent the land use of the coastal prairie area, were chosen to sample water quality. The location of these watersheds is shown in figure 1 , and the drainage areas, land use, and crops grown in each watershed are shown in table 1 above the map.

The land-use information is based on topographic maps and high-altitude aerial photographs from the 1970's and was available from

\section{EXPLANATION}

RICE

SORGHUM

SOYBEANS

$5^{\circ}$

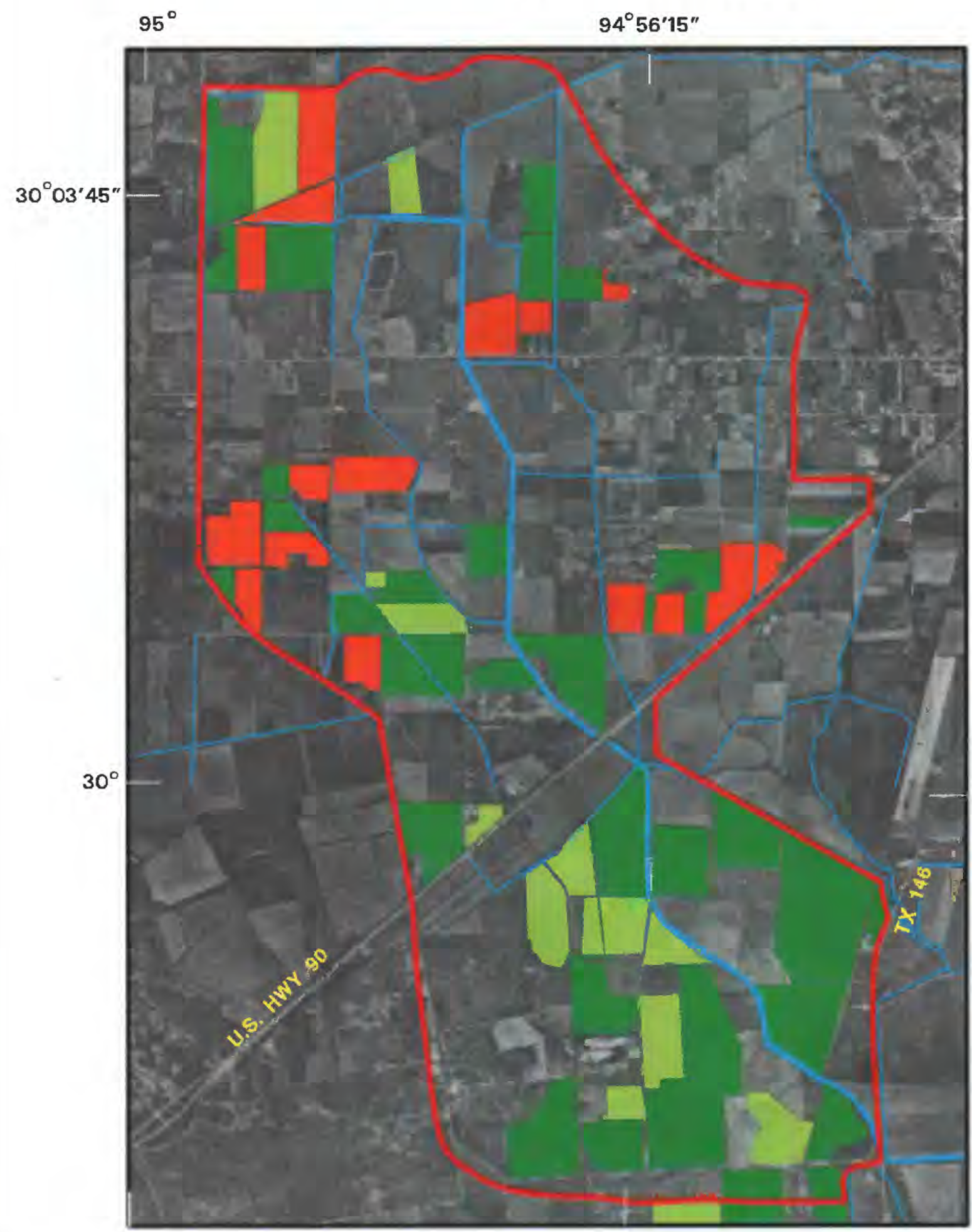

Figure 2. Streams and crops in the West Prong Old River watershed.
Geographic Information and Retrieval System (GIRAS) files (Ulery and others, 1993). Categories that made up less than 1 percent of the area and are not shown in the table include water, wetlands, and barren land. These data also have been updated with information from the 1990 census, which indicates areas of new urban development (Hitt, 1994). All three of the watersheds have more than half of the area devoted to agriculture which includes, in addition to cropland, pasture and any other agricultural areas such as turf farms, orchards, nurseries, or feedlots. East Fork is the largest watershed. The Anahuac oil field occupies 25 percent of this watershed and is classified as urban. Whites Bayou is the smallest of the three watersheds and is located just to the west of East Fork. Whites Bayou also has the highest percentage of mixed and evergreen forest. The third watershed, West Prong, is located on the west side of the Trinity River and includes the highest percentage of land in agriculture.

The crop information was obtained by use of aerial photographs of the watersheds taken during the sampling period and assistance from Consolidated Farm Service Agency (CFSA) officials in Liberty and Chambers Counties. The aerial photographs were taken at a scale of 1:24,000, and the watershed boundaries and crop information from the CFSA were overlaid on images of the aerial photographs (Zey, 1995). The crops identified through the CFSA account for most of the cropland in the watersheds. The remainder of the agricultural area may be accounted for by hay (which is generally not treated with pesticides), pasture, turf farms, and very small areas planted in rye. Figure 2 is an example of an image from the aerial photographs overlaid with the watershed boundary and crops of the West Prong watershed. Rice is the dominant crop in the watersheds of both East Fork and Whites Bayou. Rice is planted between April and mid-June, depending on the weather. The West Prong watershed has the greatest variety of crops; sorghum and soybeans are grown in addition to rice. Sorghum is planted as early as the first part of March, and soybeans are planted in the May to June timeframe. There are also some turf farms in West Prong.

\section{Pesticide Applications}

Pesticide-use estimates were made for the crops grown in the coastal prairie area. This was done by multiplying the area planted for a given crop in each watershed by a pesticide application rate estimate from the Texas Agricultural Extension Service (Bill Harris, written commun., 1991, and Glenn Avriett, written commun., 1995) and by the percentage of county area of that crop that was treated 
be related to its physical and chemical properties or its changing use. Propanil is less water soluble $\left(130 \mathrm{mg} / \mathrm{L}\right.$ at $\left.25^{\circ} \mathrm{C}\right)$ than molinate $(880$ $\mathrm{mg} / \mathrm{L}$ at $20^{\circ} \mathrm{C}$ ), has a much shorter soil halflife of 1.5 days compared to 3 weeks (Meister Publishing Company, 1995), and propanil breaks down rapidly in water. The use estimate for propanil was adjusted to reflect its partial replacement by quinlorac, but the estimate may still be high. Acifluorfen and bentazon, although shown to be extensively used, were not frequently detected. This could be explained by their physical and chemical properties. Both of these compounds break down quickly in water and the presence of sunlight. Acifluorfen has a half-life in water with continuous light of 92 hours, and bentazon has a half-life in water with photodegradation of less than 24 hours (U.S. Environmental Protection Agency, 1985 and 1987).

Three herbicides were frequently detected but did not show up in the agricultural use estimates. These were tebuthiuron, simazine, and prometon. All three of these compounds may be used for weed control in industrial areas and along highways. Simazine is also associated with turf production and may be used on turf farms in the area.

Only seven insecticides were detected at the coastal prairie sites, and all of these were detected in less than 25 percent of the samples. The most frequently detected insecticide was carbofuran, which was used on rice. Diazinon was the second most frequently detected insecticide but was not included in the compounds used on rice, sorghum, and soybeans. Diazinon is used on home gardens and farms to control a wide variety of insects. It is also used around homes for control of grubs in lawns as well as control of fleas and ticks. It is frequently detected in the Trinity River Basin, especially in the urban areas. Malathion was detected in 11 percent of the samples and was also not included in the compounds used for rice, sorghum, and soybeans. It may be used in the study area for mosquito control. Two insecticides that had relatively high use rates, carbaryl and methyl parathion, were detected in less than 10 percent of the samples. The physical and chemical properties of these insecticides may be responsible for the low number of detections. Carbaryl has been shown to have a half-life in streamwater of 24 hours (Wauchope, 1978). Methyl parathion also degrades rapidly in water with a photodegradation half-life of 8 days during the summer. Similarly, ethyl parathion, which was used on the crops but not detected in any samples, has a half-life in water with photodegradation of 1 to 10 days (Howard, 1989).

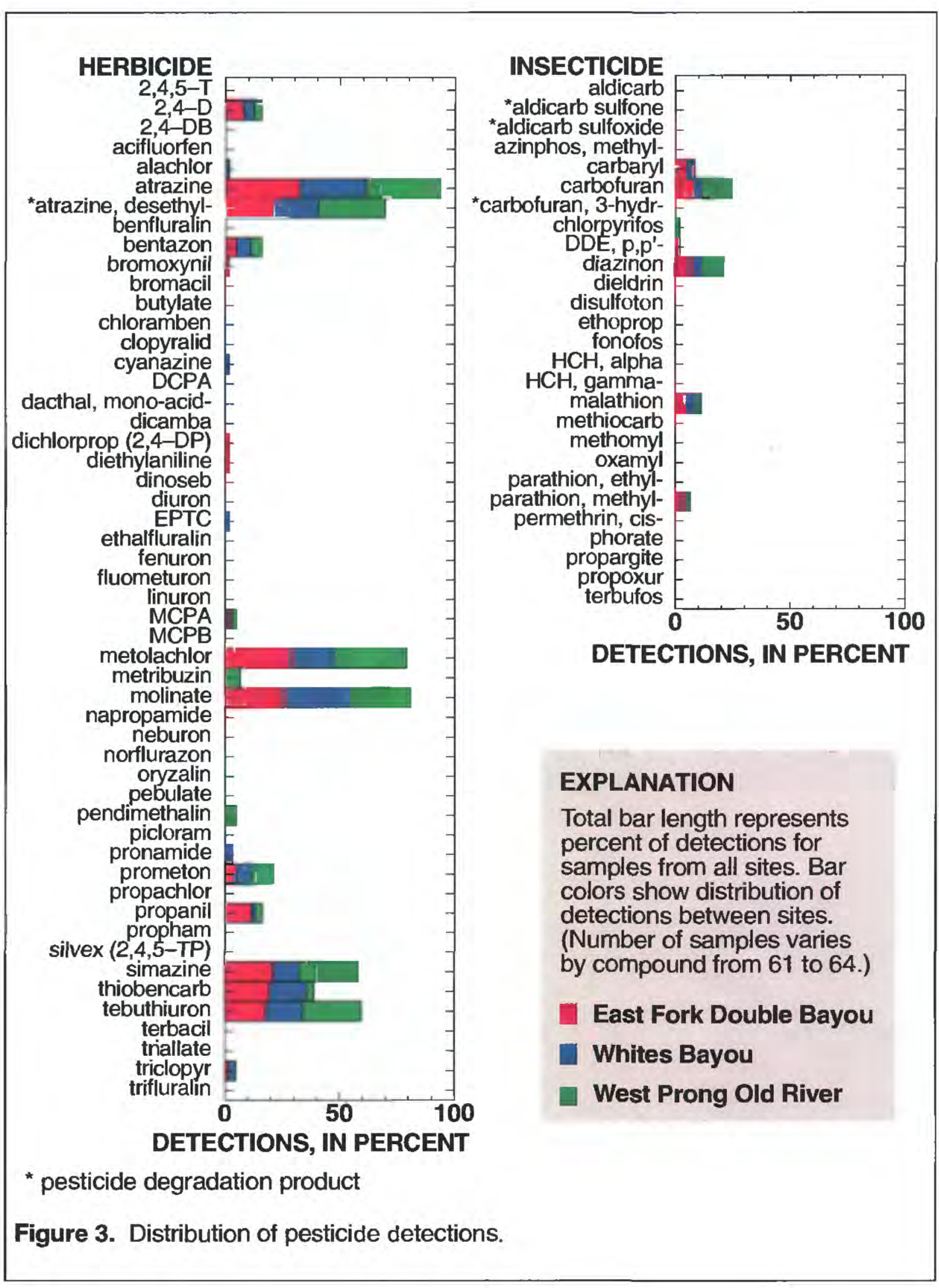

\section{Concentrations}

In addition to pesticide occurrences, it is important to consider the levels at which they are present in the streams. Concentrations of the three herbicides that were detected in more than 75 percent of the samples are shown in figure 4 . Table 3 lists the maximum and median concentrations of the three compounds. Comparing the concentrations in the streams to available water-quality standards provides a frame of reference. The U.S. Environmental Protection Agency (USEPA) maximum contaminant level (MCL) and health advisory (HA) for the compounds are listed in table 4. The MCL is the USEPA standard for the maximum permissible level of a contaminant in water that is delivered to any user of a public water system. The HA is a nonregulatory level of contaminants in drinking water that may be used for guidance in the absence of regulatory limits. The HA listed in the table is a health advisory established for an individual's lifetime ( 70 years) exposure to drinking water. This HA is established to protect against adverse health effects not related to cancer and is based on a body weight of 70 kilograms ( 150 pounds) and consumption of 2 liters per day of drinking water (Nowell and Resek, 1994).

Concentrations of these herbicides in the three watersheds appear to be consistent with the crop and pesticide-use data. Atrazine and metolachlor were frequently detected in East Fork and Whites Bayou, although no sorghum 
Table 3. Selected pesticide concentrations, estimated loads, and percentage lost to stream

[ $\mu \mathrm{g} / \mathrm{L}$, micrograms per liter; $\mathrm{kg} / \mathrm{yr}$, kilograms per year]

\begin{tabular}{|c|c|c|c|c|}
\hline $\begin{array}{l}\text { Watershed } \\
\quad \text { Pesticide }\end{array}$ & $\begin{array}{l}\text { Maximum } \\
\text { concentration } \\
(\mu g / L)\end{array}$ & $\begin{array}{c}\text { Median } \\
\text { concentration } \\
(\mu g / L)\end{array}$ & $\begin{array}{l}\text { Estimated } \\
\text { load } \\
(\mathrm{kg} / \mathrm{yr})\end{array}$ & $\begin{array}{l}\text { Estimated percentage } \\
\text { of amount applied } \\
\text { lost to stream }\end{array}$ \\
\hline \multicolumn{5}{|c|}{ East Fork Double Bayou } \\
\hline atrazine & 0.21 & 0.05 & 1.35 & * \\
\hline metolachlor & .03 & .01 & .54 & * \\
\hline molinate & 20.0 & .28 & 35.2 & 1.0 \\
\hline \multicolumn{5}{|l|}{ Whites Bayou } \\
\hline atrazine & .37 & .03 & .53 & * \\
\hline metolachlor & .02 & .01 & .15 & * \\
\hline molinate & 200 & .10 & 30.4 & 7.8 \\
\hline \multicolumn{5}{|c|}{ West Prong Old River } \\
\hline atrazine & 4.0 & .25 & 10.1 & 2.5 \\
\hline metolachlor & 1.9 & .06 & 7.1 & 1.5 \\
\hline molinate & 9.6 & .03 & 11.8 & .9 \\
\hline
\end{tabular}

* No estimated applications of this pesticide for this watershed.

Table 4. Selected pesticide standards

[USEPA, U.S. Environmental Protection Agency; $\mu \mathrm{g} / \mathrm{L}$, micrograms per liter]

\begin{tabular}{|c|c|c|}
\hline Pesticide & $\begin{array}{l}\text { USEPA maximum contaminant level } \\
\qquad(\mu \mathrm{g} / \mathrm{L})\end{array}$ & $\begin{array}{l}\text { USEPA health advisory } \\
\text { ( } \mu g / L)\end{array}$ \\
\hline atrazine & 3.0 & 3.0 \\
\hline metolachlor & no standard available & 100 \\
\hline molinate & no standard available & no standard available \\
\hline
\end{tabular}

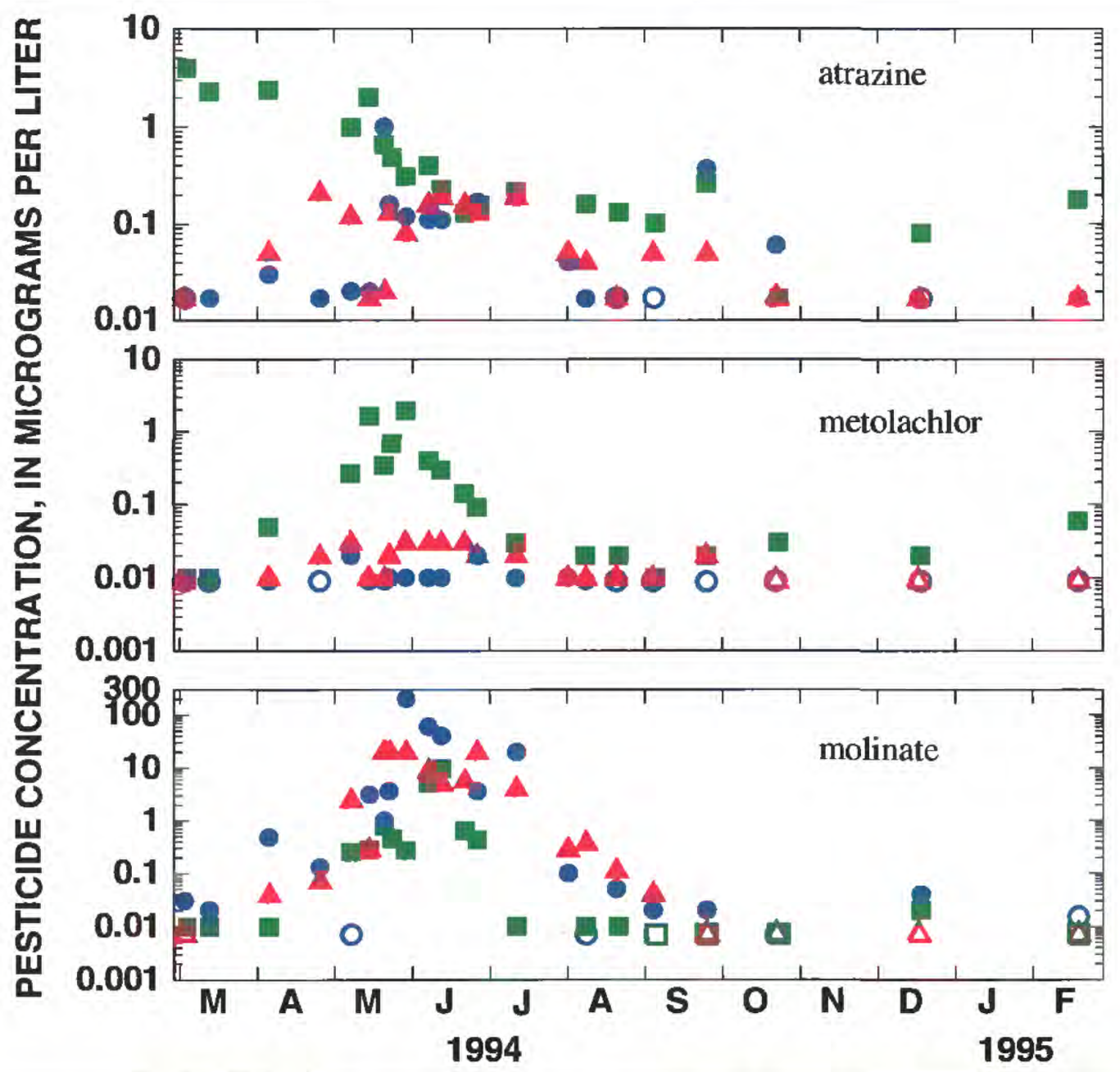

EXPLANATION

$\triangle$ East Fork Double Bayou

- Whites Bayou

West Prong Old River

Open symbols indicate value is "less than" value shown. Minimum reporting level for atrazine is $0.017 \mu \mathrm{g} / \mathrm{L}$, metolachlor is $0.009 \mu \mathrm{g} / \mathrm{L}$, and molinate is $0.007 \mu \mathrm{g} / \mathrm{L}$.

Figure 4. Seasonal pesticide concentrations for selected compounds.

or soybeans were grown in the watersheds. However, concentrations were lower in these two streams than in West Prong, where atrazine and metolachlor were applied to sorghum and soybeans in the watershed. The highest concentration of atrazine, $4 \mu \mathrm{g} / \mathrm{L}$, was in March at West Prong. This value exceeds the MCL of $3 \mu \mathrm{g} / \mathrm{L}$, but all other concentrations of atrazine at all of the sites were below the MCL. The application of atrazine in the pre-emergent product Bicep on sorghum, which is planted in March, corresponds to this peak concentration. Metolachlor concentrations were also highest at West Prong, but the seasonal peak was a little later, with $1.9 \mu \mathrm{g} / \mathrm{L}$ occurring in May. This may correspond to application of metolachlor to soybeans, which are planted in this timeframe. All values of metolachlor were well below the HA of 100 $\mu \mathrm{g} / \mathrm{L}$. Molinate concentrations were highest in the two watersheds where rice is the predominant crop, East Fork and Whites Bayou. All three watersheds show a similar seasonal pattern with the highest molinate concentrations occurring in May and June, corresponding to the beginning of the rice-growing season and the application of molinate. The highest molinate concentration was $200 \mu \mathrm{g} / \mathrm{L}$ at Whites Bayou. No drinking water standards are available for molinate.

\section{Loads}

While concentrations show the levels of the pesticides in the stream. loads are necessary to show the total amount of pesticides transported by the streams over time. Yearly loads for atrazine, metolachlor, and molinate were estimated using the unbiased stratified ratio estimator method (Thomann and Mueller, 1987). This method uses the concentrations and discharges measured during sampling along with the mean flow for the period to determine the load. It also allows for the data to be divided into two or more "seasons" to allow for variable flow or concentrations. In this case, for each watershed and pesticide combination, the data were split into two groups; one group was the growing season, which was determined from the seasonal concentration graph, and the other group contained the rest of the data (when the concentrations were generally lower in the fall and winter). Using a mean value for flow made the load estimate possible even though flow was not measured as frequently during the fall and winter. Also, for the compounds which show a significant yearly load, the load during the fall and winter made up a very small percentage ( 0.3 to 2.8 percent) of the yearly load because of the low concentrations during this period. The mean flow for the entire sampling period was 1.5 cubic meters per second $\left(\mathrm{m}^{3} / \mathrm{s}\right)$ at East Fork, $0.5 \mathrm{~m}^{3} / \mathrm{s}$ at Whites Bayou, and $0.6 \mathrm{~m}^{3} / \mathrm{s}$ at West Prong. 
Table 2. Estimated pesticide applications by crop and watershed

[kg, kilograms; - , none known to be applied]

\begin{tabular}{|c|c|c|c|c|c|}
\hline \multirow[b]{2}{*}{ Crop } & \multirow{2}{*}{$\begin{array}{l}\text { Pesticide } \\
\text { actlve ingredient }\end{array}$} & \multirow{2}{*}{$\begin{array}{l}\text { Pesticide } \\
\text { trade } \\
\text { name }\end{array}$} & \multicolumn{3}{|c|}{$\begin{array}{l}\text { Estimated amount applied } \\
\qquad(\mathrm{kg})\end{array}$} \\
\hline & & & $\begin{array}{l}\text { East } \\
\text { Fork }\end{array}$ & $\begin{array}{l}\text { Whites } \\
\text { Bayou }\end{array}$ & $\begin{array}{l}\text { West } \\
\text { Prong }\end{array}$ \\
\hline \multicolumn{6}{|l|}{ RICE } \\
\hline & acifluorfen & Blazer & 49.5 & 5.50 & 17.6 \\
\hline & bentazon & Basagran & 165 & 18.3 & 58.6 \\
\hline & carbaryl & Sevin & 554 & 61.6 & 197 \\
\hline & carbofuran & Furadan & 269 & 29.9 & 95.6 \\
\hline & methyl parathion & Penncap-M & 165 & 18.3 & 58.6 \\
\hline & molinate & Ordram, Arrosolo & 3,520 & 391 & 1,250 \\
\hline & pendimethalin & Prowl & 66.0 & 7.33 & 23.4 \\
\hline & propanil & Propanil, Arrosolo & 2,090 & 232 & 742 \\
\hline & thiobencarb & Bolero & 990 & 110 & 351 \\
\hline \multicolumn{6}{|c|}{ SORGHUM } \\
\hline & atrazine & Bicep & - & - & 410 \\
\hline & chlorpyrifos & Lorsban & - & - & 29.7 \\
\hline & ethyl parathion & Parathion & - & - & 37.1 \\
\hline & metolachlor & Bicep & - & - & 481 \\
\hline \multicolumn{6}{|c|}{ SOYBEANS } \\
\hline & acifluorfen & Blazer & - & - & 691 \\
\hline & alachlor & Lasso & - & - & 287 \\
\hline & bentazon & Basagran & - & - & 346 \\
\hline & carbaryl & Sevin & - & - & 173 \\
\hline & linuron & Lorox & - & - & 86.4 \\
\hline & methyl parathion & Penncap-M & - & - & 259 \\
\hline & metolachlor & Dual & - & - & 259 \\
\hline & metribuzin & Lexone & - & - & 86.4 \\
\hline & permethrin & Ambush & - & - & 49.2 \\
\hline
\end{tabular}

with the pesticide. These estimates are given in table 2. Only those pesticides included in NAWQA laboratory analyses are shown.

The compounds with the highest use on rice are the herbicides molinate and propanil. These compounds are used individually and in combination (as trade name Arrosolo) to control a variety of grasses and broadleaf weeds. Another herbicide, quinlorac (trade name Facet), which is not included in NAWQA analyses, is replacing some of the propanil use. The other herbicides used on rice are thiobencarb, acifluorfen, bentazon, and pendimethalin. Most of the herbicide applications for rice are before planting or very early in the growing season. The insecticide carbaryl is used on rice to control stink bugs and army worms. Carbofuran is used to control rice water weevils, and methyl parathion is used for additional stink bug control. The use of the insecticides on rice varies from year to year with the severity of insect problems.
Sorghum is treated with a much smaller number of pesticide compounds. The herbicides atrazine and metolachlor are used in combination (as the trade name Bicep) for preemergent weed control. Two insecticides are used. Ethyl parathion is used for the control of midges, and chlorpyrifos is used to control sorghum headworm.

Several herbicides are used for weed control on soybeans. Acifluorfen is used in the greatest amount, followed by bentazon, alachlor, metolachlor, linuron, and metribuzin. Three insecticides are used on soybeans. Methyl parathion is used for the control of stink bugs, and carbaryl and permethrin are used for worm control.

Other pesticide uses have not been quantified but may include use of 2,4-D for weed control in canals and on rights-of-way, the use of various herbicides and insecticides on turf farms in the area, and additional herbicide use for the control of vegetation in industrial areas such as oil fields.

\section{Pesticide Sampling}

Water samples were collected at one site in each of the three watersheds from March 1994 through February 1995. More than 20 samples were collected at each site. Additional samples were collected to assure that consistent field and laboratory results were produced. Sampling frequency varied from weekly during the spring and summer growing season to once every 2 months during the winter. Stream stage was measured at each sampling and three times per week at each site from April through September.

In addition to gas chromatography/mass spectrometry and high-pressure liquid chromatography methods for pesticides, laboratory analyses included major inorganic ions, nutrients, and suspended sediment. Field measurements included stream stage and discharge, water temperature, $\mathrm{pH}$, dissolved oxygen, and specific conductance.

\section{Pesticide Results}

The coastal prairie pesticide data were summarized as frequency of detections for each pesticide. Concentrations of the most frequently detected compounds were graphed versus time and compared to available waterquality standards. The amounts of these frequently detected compounds transported in the streams over time were also estimated and compared to the amounts applied in the watersheds.

\section{Occurrence}

The first level of data analysis for the pesticides is to identify which compounds are present, or occurring, in the streams. One measure of pesticide occurrence is the frequency of detections among all the samples. Figure 3 is a bar graph showing the distribution of detections for all the pesticide samples in the coastal prairie area. The figure lists herbicides and insecticides separately and shows that herbicides are much more frequently detected than insecticides.

Three herbicides-atrazine, metolachlor, and molinate - were detected in more than 75 percent of the samples. These three herbicides were among the most highly used compounds on rice, sorghum, and soybeans. Desethylatrazine, a breakdown product of atrazine, was also detected in nearly 70 percent of the samples. Thiobencarb was detected in about 40 percent of the samples and was also among the most highly used compounds. Propanil was second in estimated total use but was only detected in 16 percent of the samples. The low number of detections for propanil could 
For East Fork and Whites Bayou, the growing season mean flow was lower than that for the rest of the year $\left(1.4 \mathrm{~m}^{3} / \mathrm{s}\right.$ during the growing season compared to $1.8 \mathrm{~m}^{3} / \mathrm{s}$ for East Fork and $0.5 \mathrm{~m}^{3} / \mathrm{s}$ compared to $0.6 \mathrm{~m}^{3} / \mathrm{s}$ for Whites Bayou). At West Prong, the growing season mean flow was greater at $0.8 \mathrm{~m}^{3} / \mathrm{s}$ compared with $0.2 \mathrm{~m}^{3} / \mathrm{s}$ during the rest of the sampling period.

Like the concentrations, the loads of these pesticides were higher in the watersheds where they were applied to crops. The estimated loads are listed in table 3 . Estimated yearly loads for molinate were greater than 11 kilograms per year $(\mathrm{kg} / \mathrm{yr})$ in each of the three watersheds, while atrazine and metolachlor loads were clearly greater in West Prong, where the pesticides are known to be extensively applied.

The percentage of pesticide applied that was lost to the stream was calculated using the estimates of pesticide use and yearly loads. This percentage could not be calculated for atrazine and metolachlor in the two watersheds where the use of the pesticides on the major crops was not documented. The percentages are also listed in table 3. In the West Prong watershed, the percentage lost to the stream for atrazine was 2.5 percent and for metolachlor was 1.5 percent. The percentage lost to the stream for molinate was near 1 percent in both the East Fork and West Prong watersheds and 7.8 percent in Whites Bayou. As discussed above, Whites Bayou showed the highest single concentration of molinate at $200 \mu \mathrm{g} / \mathrm{L}$. In comparison, a study of relations between the use of 26 pesticides and riverine flux in the Mississippi River Basin in 1991 showed values for loss of atrazine from 0.6 to 2.0 percent and metolachlor from 0.5 to 0.9 percent. Values for all 26 pesticides ranged from less than 0.01 to 10.5 percent (Larson and others, 1995).

\section{Summary}

Water-quality samples were collected from three watersheds in the coastal prairie area immediately upstream from Trinity Bay. The three watersheds are representative of this area where agriculture is an important land use and the major crops grown are rice, sorghum, and soybeans. Results of this sampling include the following:

- Twenty-nine pesticides were detected in one or more of more than 60 surface-water samples from the three coastal prairie streams

- Herbicides were detected more frequently than insecticides
- The most frequently detected compounds were the herbicides atrazine, metolachlor, and molinate

- In general, concentrations and loads of atrazine, metolachlor, and molinate were highest in the watersheds where more had been applied to rice, sorghum, and soybeans

- Peak concentrations of atrazine, metolachlor, and molinate occurred in the spring around the time of their application

- Maximum concentrations of atrazine and metolachlor were almost always below drinking-water standards set by USEPA; no standards are available for molinate

\section{References}

Hitt, Kerie, 1994, Refining 1970's land-use data with 1990 population data to indicate new residential development: U.S. Geological Survey Warer-Resources Investigations Report 94-4250, 15 p.

Howard, P.H. (ed.), 1989, Handbook of environmental fate and exposure data for organic chemicals, v. III-Pesticides: Chelsea, Mich., Lewis Publishers, 684 p.

Larson, S.J., Capel, P.D., Goolsby, D.A., Zaugg, S.D., and Sandstrom, M.W., 1995, Relations between pesticide use and riverine flux in the Mississippi River Basin: Chemosphere, v. 31, no. 5, p. 3,305-3,321.

Meister Publishing Company, 1995, Farm chemicals handbook'95: Willoughby, Ohio, Meister Publishing Company, 922 p.

National Oceanic and Atmospheric Administration, National Ocean Service, 1994, Climatological Data-Texas: Asheville, N.C., National Climatic Data Center [variously paged].

Nowell, L.H. and Resek, E.A., 1994, Standards for pesticides in water, in Ware, G.W., ed., Reviews of environmental contamination and toxicology, v. 140: New York, Springer-Verlag, $221 \mathrm{p}$.

Thomann, R.V. and Mueller, J.A., 1987, Principles of surface water quality modeling and control: New York, Harper Collins Publishers, 644 p.

Ulery, R.L., Van Metre, P.C., and Crossfield, A.S., 1993, Trinity River Basin, Texas: Water Resources Bulletin, v. 29, no. 4, p. 685-711.

U.S. Environmental Protection Agency, 1985, Pesticide fact sheet for bentazon and sodium bentazon: Washington, D.C., Office of Pesticide Programs, Fact Sheet 64, 10 p.

1987, Acifluorfen health advisory draft report, August 1987: Washington, D.C., Office of Drinking Water.

Wauchope, R.D., 1978, The pesticide content of surface water draining from fields - A review: Journal of Environmental Quality, v. 7 , no. 4 , p. $459-472$.

Zey, E.B., 1995, National Water-Quality Assessment Program-A GIS application for the Texas Coastal Prairie Survey: College Station, Texas A\&M University, Rangeland Ecology and Management, Professional Paper, $42 \mathrm{p}$.

Any use of trade, product, or firm names is for descriptive purposes only and does not imply endorsement by the U.S. Government.

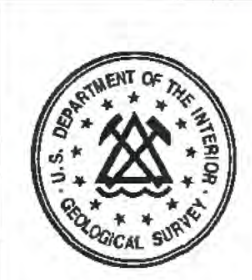

In 1991, the U.S.

Geological Survey, U.S.

Department of the Interior, began a National Water-

Quality Assessment

(NAWQA) Program. The long-term goals of the NAWQA Program are to describe the status of and trends in the quality of a large representative part of the Nation's surface-and ground-water resources and to identify the major factors that affect the quality of these resources. In addressing these goals, the NAWQA Program will produce water-quality information that is useful to policymakers and managers at Federal, State, and local levels.

Studies of up to 60 hydrologic systems that include parts of most major river basins and aquifer systems are the building blocks of the national assessment. The 60 study units range in size from less than 1,000 to more than 60,000 square miles and represent 60 to 70 percent of the Nation's water use and population served by public water supplies. Twenty investigations began in 1991, 15 investigations began in 1994, and 20 are scheduled to begin in 1997.

Information on technical reports and hydrologic data related to the NAWQA Program can be obtained from:

Project Chief - Trinity River Basin NAWQA Study U.S. Geological Survey

8011 Cameron Road

Austin, TX 78754-3898 